Article

\title{
Recasting the Significant: The Transcultural Memory of Alexander von Humboldt's Visit to Philadelphia and Washington, D.C.
}

\author{
James F. Howell \\ Department of German Studies, University of Arizona, 9720 N. Oak Shadows Pl., Tucson, AZ 85737, USA; \\ jfhowell@email.arizona.edu
}

Academic Editor: Bernd Fischer

Received: 1 May 2016; Accepted: 27 June 2016; Published: 1 July 2016

\begin{abstract}
Alexander von Humboldt was internationally known as a world traveler, having collected data and analyzed samples from five of the world's seven continents. He spoke several languages fluently, and split most of his adult life between the cosmopolitan centers of Berlin and Paris. The great deal of time Humboldt spent in Latin America, along with his staunch belief in human equality, led to his reverence in those countries. Indeed, Humboldt was a world citizen in the truest sense of the word. But what of the United States? What claim can this nation make to the heritage and legacy of the world-exploring baron? A brief stop in Philadelphia and Washington, D.C. at the end of Humboldt's expedition to the equatorial regions of the Americas seems to suffice. This short stay, along with the Humboldt-Jefferson correspondence, constitutes the great American link in Humboldt studies, a link whose nature and importance has, over the years, received an exaggerated amount of attention from authors writing for an American audience. The following analysis, using the tools of transcultural memory studies, investigates why this relatively insignificant event in a long and storied life assumes an inflated role in current accounts of the life and work of Alexander von Humboldt.
\end{abstract}

Keywords: Alexander von Humboldt; cultural memory; transcultural memory; Thomas Jefferson; Founding Fathers

\section{Humboldt's Arrival in the United States}

On 24 May 1804, Alexander von Humboldt arrived in Philadelphia, marking the beginning of his one and only visit to the United States. Between his arrival and departure on June 30th of the same year, Humboldt traveled between Philadelphia and Washington, D.C., meeting with scientists and dignitaries at every stop. Humboldt was the talk of the new republic, indeed the world, after the completion of his five-year scientific and ethnographic survey of South and Central America. During his almost six weeks in the United States, Humboldt's inquisitive hosts received him warmly, and he returned the warmth, remarking that the time spent in Washington and Philadelphia was "the most delightful of [my] life" ([1], p. 24), and that he considered himself from then on to be "half an American" ([2], p. ix). Although Humboldt did enjoy his stay in the United States and appreciated the connections he made there, he wrote very little about this pleasant and short detour in his long and storied travels. When later summarizing the final phase of his voyage, Humboldt merely remarked that he sailed from Havana to Bordeaux "by the way of Philadelphia" ([1], p. 30). This succinct characterization seems almost unthinkable when compared to recent textual depictions of Humboldt published in the United States.

With the notable exception of Mary Louise Pratt's volume Imperial Eyes: Travel Writing and Transculturation, Humboldt and his work have experienced an overwhelmingly positive reception in the United States over the past 25 years. In addition to this general positivity, another hallmark of 
American Humboldt literature is the aforementioned visit to Philadelphia and Washington, D.C. in the late spring of 1804. Recently, writers in the United States have interpreted this short stay not merely as a cornerstone of Humboldt's influence on American culture during the nineteenth century, but also as a defining moment in the Prussian baron's life and intellectual career. Although Humboldt's visit and his connection to the Founding Fathers certainly did not damage his notoriety in the United States during the course of the nineteenth century, it is problematic to overemphasize the relevance of these encounters. Indeed, the connections and correspondence Humboldt initiated with numerous American scientists and artists in Paris and Berlin after 1804 were more important in terms of his impact on American science and exploration. Contrary to the representations in many current accounts, the most probable source of the respect and popularity Humboldt enjoyed in the United States came from the translation and publication of the first several volumes of his magnum opus, Kosmos. This work was an international sensation, and within the United States its impact was felt and celebrated by the likes of Ralph Waldo Emerson, Walt Whitman, Henry David Thoreau, and Edgar Allan Poe. Why, then, does this brief and marginally relevant chapter in a life otherwise overflowing with acquaintances and accolades take such a central role in America's modern understanding and representation of Alexander von Humboldt? This investigation will demonstrate the ways in which Humboldt and his visit to the United States are currently presented to American audiences, as well as analyze the transcultural and mnemonic processes involved in the reintroduction of Alexander von Humboldt to American cultural memory.

\section{Framing Humboldt's Visit}

One need not look far to find the narrative centrality of Humboldt's visit in contemporary American texts. Humboldt's presence on the eastern seaboard and his subsequent relationship with the Founding Fathers represent the starting point, the turning point, or the conclusion of American accounts of his life and works. Aaron Sachs, the author of The Humboldt Current: Nineteenth-Century Exploration and the Roots of American Environmentalism, begins his work with the following harrowing and adventurous account: "It would have been easier to sail straight back to Europe. Politics and weather both favored the conservative course: to make the detour from Havana to Philadelphia, his ship would be forced to brave a British naval blockade and risk a dangerous stretch of water at the beginning of hurricane season" ([3], p. 1). Here, Humboldt's visit to the United States serves as the introduction to Humboldt and his biography. Only later does the reader learn in full detail from Sachs about Humboldt's background and accomplishments. The explorer's scientific influence and contributions to American environmentalism-Sach's central themes-initially assume a secondary role to the establishment of Humboldt's true credentials: his connection to the founders, and thereby to the founding, of the new republic. This association bestows a level of authenticity and indigeneity to the influence Humboldt exercised on the imagination and training of early American explorers and scientists. Humboldt impacted the American intellectual tradition not only through books and articles as a distant European scholar; rather by highlighting and prioritizing the dangerous passage from Havana to Philadelphia and the subsequent stay in the United States, Humboldt's story becomes, in part, an American story.

Laura Dassow Walls, author of Passage to Cosmos: Alexander von Humboldt and the Shaping of America, employs Humboldt's visit to Philadelphia and Washington, D.C. as a turning point in the narrative of Humboldt's biography, as well as in her own investigation. Although Walls' account of Humboldt's life does not begin with his time in Philadelphia and Washington, D.C., these events are afforded special attention and are represented in a way reminiscent of Sach's narrative. As seen in the following selection, Walls frames Humboldt's decision to brave the Bahama Strait in familiarly courageous and daring terms: "Beyond the 'moral obligation' he felt to see the world's lone functioning republic, there was every reason to avoid the detour. Humboldt was desperate to get himself, his friends, and his collections safely home to Paris. [...] Heading north risked losing everything they had with them to the British blockades of U.S. ports-assuming his ship was spared by the 
notorious Atlantic storms" ([2], p. 99). This dramatic account of Humboldt's fateful decision to visit the United States initiates the second half of Walls' analysis, in which she begins to shift her focus away from Humboldt's biography and onto his influence on nineteenth-century American literary culture. Although Humboldt's fame in English-speaking North America would truly blossom with the first translations of Kosmos in 1845, Walls, among others, claims that the seeds had already been planted in the late spring of 1804 .

Gerard Helferich, in his work Humboldt's Cosmos: Alexander von Humboldt and the Latin American Journey that Changed the Way We See the World, utilizes Humboldt's brief stopover in the United States to frame the remainder of the explorer's biographical narrative after having completed his American travels. The twelfth and final chapter of Helferich's book bears the title of "Washington, Paris, and Berlin" [4]. This condensation of the final two-thirds of Humboldt's life is indeed noteworthy, as it seemingly gives his time spent in Washington equal weight to his years spent living and working in Paris (1807-1827) and in Berlin (1827-1859). It should, of course, be noted that the biographical narrative crafted by Helferich focuses on Humboldt's experiences in South and Central America, and therefore leaves little space for details regarding his life prior to and following the years 1799-1804. Considering, however, the fact that the vast majority of Humboldt's scientific engagement and literary activity took place following his return to Europe, Helferich's choice is truly remarkable. It suggests that visiting the United States and encountering Thomas Jefferson profoundly affected Humboldt and his legacy in a way equal to the composition of Kosmos, the Russian Expedition of 1829, or participation in the nineteenth-century scientific discourses centered in Paris. These accounts make it clear that visiting the United States was no mere fancy for Humboldt on his return journey; indeed, American authors go to great lengths to suggest that some kind of imperative was at work, compelling Humboldt to look upon this new republic with his own eyes, and meet the men and women who brought it about.

Perhaps the most interesting use of Humboldt's visit to frame a biographical narrative is employed by David McCullough in his essay on Humboldt entitled "Journey to the Top of the World." McCullough, like Sachs, begins his account with Humboldt's arrival in the United States in May of 1804; unlike Sachs, however, McCullough does not reveal Humboldt's identity until the reader has been introduced to a well-known cast of American characters. All the reader knows of the "aristocratic young German" on the first page is that he had "come to pay his respects to the president of the new republic, Thomas Jefferson, a fellow 'friend of science,' and to tell him something of his recent journeys through South and Central America. For the next several weeks he did little else but talk, while Jefferson, on their walks about the White House grounds; or James Madison, the secretary of state; or the clever Mrs. Madison; or Albert Gallatin, the secretary of the treasury; or those who came to dine in with the president or to do business with him, listened in awe" ([5], p. 3). Only after the reader is securely ensconced in the thoroughly American context does McCullough reveal on the second page that “The young man's name was Humboldt, Alexander von Humboldt—Friedrich Wilhelm Karl Heinrich Alexander von Humboldt—or Baron von Humboldt, as he was commonly addressed" ([5], p. 4). Although not even lasting six weeks, Humboldt's presence in the newly established United States and his subsequent relationship with the Founding Fathers constitute an axis around which current American historical narratives revolve.

\section{Humboldt and the Founding Fathers}

Recent American accounts associate Humboldt's imperative to visit the United States with his desire to meet and consult with one particular Founding Father. As Joyce Appleby succinctly puts it in her volume Shores of Knowledge: New World Discoveries and the Scientific Imagination: "The purpose of this final leg of their voyage was to meet the president, Thomas Jefferson [...]" ([6], p. 224). Sachs echoes Appleby's assertion in more detail: "If any particular person in the young Republic could have quieted Humboldt's wanderlust for a more prolonged period, it would probably have been Thomas Jefferson himself. President not only of the nation, but also of its foremost Philosophical Society, Jefferson seems to have been the real object of Humboldt's visit to the United States"' ([3], p. 3). 
Humboldt had introduced himself to Jefferson in a letter, expressing his interest in discussing some of his paleontological finds from the Andes with the president. He soon found in Jefferson a gracious and intellectually equal host. As David McCullough states: "But there they were in Washington for several days, two of the most remarkable men of their time, fellow spirits if ever there were, talking, talking endlessly, intensely, their conversation having quickly ranged far from fossil teeth" ([5], p. 4). The representation of Jefferson in many of these texts appears as a personification of the new nation itself, an embodiment of its growth, curiosity, and potential. And in accordance, Humboldt's correspondence with Jefferson has come to symbolize in many cases Humboldt's continued interest in and preoccupation with the United States. As Helferich explains: "The two men would correspond for many years, and Jefferson's high regard for Humboldt is obvious in his letters. [...] The friendship, rooted in their shared political philosophy and common love of science, would endure for more than twenty years, until Jefferson's death in 1826" ([4], p. 299). As will later be argued, however, this epistolary connection proves to be tenuous at best.

Jefferson is not the only Founding Father with ties to Humboldt, a fact that is continually underlined in the American investigations of the last 25 years. The best example of this connection between Humboldt and the revolutionary generation is provided by Walls in Passage to Cosmos. Like McCullough and Sachs, Walls mentions in detail Humboldt's relationship with James and Dolley Madison. Unlike her counterparts, though, Walls goes on to discuss Humboldt's consultations with other, lesser-known Founding Fathers, such as Dr. Benjamin Rush: "Over several visits with the famous physician Benjamin Rush - the obstinate and passionate reformer who had ridden to the First Continental Convention with John Adams and signed the Declaration of Independence next to Benjamin Franklin-Humboldt shared his speculations over the moral influence of New World gold and silver" ([2], p. 105). A textual connection emerges among Adams, Franklin, and the signing of the Declaration of Independence through Rush and his interactions with Humboldt. Walls again emphasizes this connection to Franklin when she notes Humboldt's activities in Philadelphia: "The members of the American Philosophical Society, the premier learned society of the United States (founded by Benjamin Franklin in 1743), adopted Humboldt as one of their own, voting him to full membership at their next meeting. [...] It was probably in the fine new building of the Library Company of Philadelphia (founded by Franklin in 1731) that Humboldt shouted for joy when he read the announcement that his irreplaceable manuscripts had arrived safely home" ([2], p. 101). Here the reader is presented with Humboldt's connection to Franklin expressed either in his membership in an organization, or in a joyous, yet merely probable, event. Some of these connections are tenuous at best, but perhaps the most interesting is the way in which Walls creates a textual connection between Humboldt and George Washington: "One day the party set off for Mount Vernon, where the visitors drank in the view while [Charles Wilson] Peale mourned for the good old days when he sat and drank with George Washington. Peale introduced Humboldt to Billy Lee, the last of Washington's slaves, who had been granted freedom and an annuity in his will" ([2], pp. 102-3). In this passage, Walls not only connects Humboldt to the central figure among the Founding Fathers, she also connects him to the most problematic and divisive element of their legacy. The establishment of such a link to the Founding Fathers and the complexities of American slavery is remarkable, to be sure, as Humboldt was a lifelong abolitionist and an ardent opponent of the slave trade in the Americas.

\section{The Constitution of Convention}

Perhaps the most intriguing elevation of Humboldt's visit to the United States and his relationship with Thomas Jefferson comes in the form of two recent books written by European authors for American audiences. The first volume, Humboldt and Jefferson: A Transatlantic Friendship of the Enlightenment by Sandra Rebok, a European scholar working out of the Spanish National Research Council in Madrid, appeared in 2014, and fits neatly into the mold of American Humboldt literature. In Rebok's account, the reader again finds Humboldt's imperative to visit the United States: "From Cuba they initially intended to return to Europe and thus conclude their expedition, but instead they took the Spanish 
ship Concepción to Philadelphia and added five weeks in the United States to their journey. As we will see, this unplanned visit would assume a special importance in Humboldt's life" ([1], p. 11). The special importance alluded to by Rebok takes the form of Humboldt's subsequent friendship and correspondence with Jefferson. Rebok identifies this relationship as being of extreme importance to both men, as well as being an exemplar of enlightened, transatlantic discourse in a cosmopolitan age. According to Rebok, Humboldt's experience in the United States and his connection to its founders was indeed formative: "He had met the Founding Fathers and architects of the first independent nation on the American continent, and he had seen for himself the functioning of the first republican institutions in the New World. This was the realization of ideals he passionately embraced" ([1], p. 31).

Although Rebok's text is irreplaceable as perhaps the most detailed and thoroughly researched account of Humboldt's visit to Philadelphia and Washington, D.C., it contains information that undermines the supposedly strong epistolary connection between Humboldt and Jefferson celebrated in the title, as well as the overall importance of Humboldt's detour to the United States. Rebok notes that Humboldt was perhaps one of the most prolific letter writers of his day, penning an estimated fifty thousand letters in his lifetime. Jefferson, although not nearly reaching Humboldt's total, still drafted some nineteen thousand letters. The number of extant letters written by the two men to one another, however, totals a mere fourteen: eight letters from Humboldt to Jefferson, and six letters from Jefferson to Humboldt ([1], pp. 53,54). This sum certainly bespeaks neither a close and enduring friendship nor a passionate connection to an idealized state; rather it seems much more to be a sign of general good will and respectful interest on the part of both men. It is telling, for instance, that many of the succinct letters were written when the two correspondents sent, received, or requested each other's publications as a gift. Even a brief correspondence and the polite exchange of written materials can, to be sure, have a profound impact on a person's life or an intellectual environment, but there simply is no evidence in the extant textual record to suggest that such was the case between Humboldt and Jefferson. In the end, Rebok's focus seems to be at times misplaced and her study, although thoroughly researched, faces many of the same interpretational issues experienced by her American counterparts.

The second work on Humboldt by a European author for an American audience is Andrea Wulf's The Invention of Nature: Alexander von Humboldt's New World, published in 2015. In this-the most recent and best-selling work on Humboldt to appear in the United States over the last several decades-all of the previously mentioned American Humboldt conventions can be found. Echoing the suspenseful depictions of the stormy passage from Havana to Philadelphia crafted by Walls and Sachs, Wulf provides the following riveting account:

It was as if the sea were about to swallow them. Huge waves rolled on to the deck and down the stairway into the belly of the ship. Humboldt's forty trunks were in constant danger of flooding. They had sailed through a hurricane and for six long days the winds would not stop, pounding the vessel with such force that they could not sleep or even think. The cook lost his pots and pans when the water came gushing in, and was swimming rather than standing in his galley. No food could be cooked and sharks circled the boat. The captain's cabin, at the ship's stern, was flooded so high that they had to swim through it, and even the most seasoned sailors were tossed across the deck like ninepins. Fearing for their lives, the sailors insisted on more brandy rations, intending, they said, to drown drunk. Each wave that rolled towards them seemed like a huge rock face. Humboldt thought that he had never been closer to death ([7], p. 94).

And all of this so that Humboldt could see with his own eyes the new country that supposedly embodied his most heartfelt political and philosophical beliefs, as well as "meet Thomas Jefferson, the third President of the United States. For five long years, Humboldt had seen nature at its best—lush, magnificent and awe-inspiring-and now he wanted to see civilization in all its glory, a society built as a republic on the principles of liberty" ([7], p. 95). Wulf also reminds the reader that it is not only Jefferson with whom Humboldt made a connection while in Philadelphia and Washington, D.C. Madison and Gallatin are also featured prominently in the narrative, along with other luminaries of 
the early republic. Most notably, Wulf employs a familiar literary tactic, which allows Humboldt to forge associations with Founding Fathers in absentia. In a scene reminiscent of Walls' account, Wulf describes how "Humboldt travelled to Mount Vernon, George Washington's estate, some fifteen miles south of the capital. Though Washington had died four and a half years previously, Mount Vernon was now a popular tourist destination and Humboldt wanted to see the home of the revolutionary hero" ([7], p. 101). Another way in which Wulf recapitulates American Humboldt literary convention is in her representation of the Jefferson-Humboldt correspondence. In the twelfth chapter of The Invention of Nature, "Revolutions and Nature: Simón Bolívar and Humboldt," Wulf presents the correspondence between Humboldt and Jefferson as a constant back and forth, in which the finer points of the Latin American independence movements were discussed in detail. With no further point of reference provided by Wulf, the Humboldt-Jefferson correspondence appears to be the primary source material for the political debates of the age. This implicit characterization is unfortunate, as the Latin American struggles for independence were only explicitly thematized in four letters, and often in passing. In Wulf's narrative, however, this was a passionate and important exchange, in which "the former American president, Thomas Jefferson, bombarded Humboldt with questions [...]" ([7], p. 148). In truth, a handful of questions spread out over a small number of short letters hardly constitutes a bombardment. As previously noted, the exchange of each other's written works was the primary purpose of the Humboldt-Jefferson correspondence. Here again, an otherwise thoroughly researched and responsibly constructed narrative of Humboldt's life and work overemphasizes a relatively minor event and the significance of a handful of encounters.

\section{The Transcultural Synthesis of Memory}

Why is it then that so much recent scholarship and popular writing published in the United States inflates the significance of Humboldt's visit to Philadelphia and Washington, D.C.? Although one might easily make charges of Americentrism or intellectual imperialism, processes of cultural memory and cultural integration are actually at work. For example, Sachs writes somewhat wistfully that: "It is tempting to wonder what Humboldt might have contributed to American politics had he moved to Washington and become an advisor to presidents instead of kings" ([3], p. 104). This statement does not advocate the explicit appropriation or annexation of Humboldt into American culture; rather it expresses much more a desire to share in Humboldt's cultural and scientific legacy. Instead of appropriation, the talk should be of incorporation. This process of incorporation can be at times a bit cumbersome and problematic, as evidenced by the exaggerated accounts in the selections above; but it is also the process by which a culture's memory adapts and reconfigures itself, so as to include a new element.

In the field of cultural memory studies, an element such as Alexander von Humboldt is best identified as a memory site. This terminology should not be understood as referring to a specific site of historical action; rather memory sites can take any number of forms, including, but not limited to, places, people, events, periods, and ideas. This distinction is essential, as cultural memory studies do not investigate actual past events per se; rather the investigation focuses on how actors in the present create representations and knowledge of the past and to what purpose. Although cultural memory "operiert [...] in beiden Richtungen: zurück und nach vorne," and "rekonstruiert nicht nur die Vergangenheit, es organisiert auch die Erfahrung der Gegenwart und Zukunft" ([8], p. 42), this is a concept that functions exclusively in the present. In other words, the remembering individual, and thereby the culture to which it belongs, is always present and active, while the event being remembered "is of the past and thus absent" ([9], p. 4).

In considering cultural memory as a process of the present, it is important to keep in mind the distinction between history and the past. History is the product of the collection and analysis of textual records of every kind, with the aim of reconstructing a realistic and accurate representation of things that have taken place. The past is also "eine kulturelle Schöpfung" ([8], p. 48), but it is not the locus of thoughtful scholarly reflection as history is thought to be; rather the past serves as a necessary, 
cognitive point of reference and satisfies "das kollektive Bedürfnis nach Sinnstiftung" ([10], p. 13). The past, unlike the material collections and institutions of history, "ensteht überhaupt erst dadurch, daß man sich auf sie bezieht" ([8], p. 31). In other words, the past, along with the memory sites into which the past is divided, serves as a means of orientation that guides cultural actors in the present.

If cultural memory is differentiated thus from history, the Age of Discovery or Charlemagne are as much points of reference as the Alamo or Auschwitz; and they therefore constitute memory sites "nicht dank ihrer materiellen Gegenständlichkeit, sondern wegen ihrer symbolischen Funktion. Es handelt sich um langlebige, Generationen überdauernde Kristallisationspunkte kollektiver Erinnerung und Identität, die in gesellschaftliche, kulturelle und politische Üblichkeiten eingebunden sind und die sich in dem Maße verändern, in dem sich die Weise ihrer Wahrnehmung, Aneignung, Anwendung und Übertragung verändert" ([10], p. 18). And these sites, much like the cultural memory they constitute, are contextually specific. Alexander von Humboldt memory sites exist in numerous cultures, but each Humboldt memory site interacts with each culture in a specific manner. The German Humboldt, for instance differs from the Venezuelan Humboldt, and each fulfills a different role in the respective cultures.

What then are the ways in which cultural memory functions? How is it that some things are remembered and celebrated while others are not? These questions get to the very heart of the representation and use of Alexander von Humboldt in recent American texts, as they highlight the role of forgetting in the processes of cultural memory. In addition to the aforementioned themes and conventions that pervade contemporary American Humboldt literature, Humboldt's absence from twentieth and twenty-first-century American culture forms a cornerstone of almost every Humboldt narrative published in the United States. As Sachs notes following his depiction of Humboldt's rough passage from the Caribbean to the Delaware River: "As far as the twenty-first century memory of Alexander von Humboldt is concerned, he may as well have gone down with his ship: many people have never even heard of him" ([3], p. 2). Helferich concurs with Sachs, in that "[a]lthough many North Americans have a vague sense of Humboldt's name [...] most would be hard pressed to give particulars" ([4], p. xx). The name might seem familiar to many Americans, considering the number of places and natural phenomena that have been named after Humboldt; but even this, as Appleby concludes, does not protect against cultural amnesia: "What astounds today is how little Humboldt is remembered. [...] Few great men have had their reputations fade so quickly, just leaving his name on a bay, peak, lake, current, sinkhole, penguin, lily, orchid, and oak whose namesake few remember" ([6], p. 229). This is truly astounding to McCullough, who reflects on the fact that Humboldt's "was a journey that would capture the imagination of the age, but that has been strangely forgotten in our own time. It is doubtful that one educated American in ten today could say who exactly Humboldt was or what he did, not even, possibly, in Humboldt, Iowa, or Humboldt, Kansas" ([5], p. 5). Some authors, such as Walls, do not merely lament the level of American ignorance regarding Humboldt. Indeed, she sees it as a deficiency in America's understanding of its own history that is in desperate need of correction: "That U.S. American literary and cultural studies have remained oblivious to Alexander von Humboldt is a scandal exactly equivalent to analyzing Romanticism without Goethe, naturalism without Darwin, modernism in ignorance of Einstein, or postmodernism without Heisenberg" ([2], p. x). American authors not only bemoan this absence, it serves as the stated raison d'etre for their work. The reintroduction of Humboldt to American culture and the recovery of Humboldt's "environmental thinking" will allow for a host of progressive cultural advances, including "a global debate over capitalism and imperial power" ([2], p. 9). Wulf alone slightly breaks with convention and reminds the American reader that not the entire world has forgotten Humboldt in the same way: "Though today almost forgotten outside of academia—at least in the English-speaking world-Alexander von Humboldt's ideas still shape our thinking. And while his books collect dust in libraries, his name lingers everywhere" ([7], p. 7).

Fittingly enough, these images of dusty libraries and tomes of neglected toponyms allude to Aleida Assmann's groundbreaking work on the role of forgetting in the processes of cultural 
memory. Assmann has identified two types of memory that shape a culture's understanding and representation of itself, and that are constantly engaged in dynamic interaction with one another. There is the active, or functional, memory of a culture, which is comprised of the memory sites being synthesized and utilized by a culture on a constant basis; and the stored, or saved memory of a culture. The functional memory of a culture can be thought of as a kind of canon that is continually invoked by cultural actors as a means of orientation and reference. No memory site in the functional memory of a culture may be assured of continued thematization, however, "[d]enn Kanonisierung bedeutet obendrein auch die transhistorische Selbstverpflichtung zu wiederholter Lektüre und Deutung. So bleiben die Bestände des Funktionsgedächtnisses trotz der Bewegung beschleunigter Innovation auf den Lehrplänen der Bildungsinstitutionen, auf den Spielplänen der Theater, in den Sälen der Museen, den Aufführungen der Konzerthallen und Programmen der Verlage. Was einen Platz im Funktionsgedächtnis einer Gesellschaft hat, hat Anspruch auf immer neue Aufführung, Ausstellung, Lektüre, Deutung, Auseinandersetzung" ([11], p. 56).

In contrast, the archived memory extant within a culture should be understood much more as "a storehouse for cultural relicts," in which memories "are not unmediated; they have only lost their immediate addressees; they are de-contextualized and disconnected from their former frames which had authorized them or determined their meaning" ([12], p. 99). The contents of a culture's stored memory have not lost any of their productive power; rather their creative energy has gone from kinetic to potential. To be sure, there is a constant back and forth between a culture's stored and functional memory; and this continual deactivation and reactivation "entsteht dadurch, dass die Grenze zwischen Funktions-und Speichergedächtnis nicht hermetisch ist, sondern in beiden Richtungen überschritten werden kann. Aus dem vom Willen und Bewusstsein ausgeleuchteten 'aktiven' Funktionsgedächtnis fallen beständig Elemente ins Archiv zurück, die an Interesse verlieren; aus dem 'passiven' Speichergedächtnis können neue Entdeckungen ins Funktionsgedächtnis heraufgeholt werden." ([11], p. 57). The dynamic relationship between the two forms of cultural memory provides cultural actors with an almost unlimited set of memory sites with which to work. In turn, cultural actors select, activate, and modify these memory sites based on their current needs and aspirations.

Taking all of this into consideration, the textual representations of Humboldt in the United States can be understood as an appeal to the reading public to reincorporate the Humboldt memory site into the functional memory of American culture. Time and again, these American and European authors decry Humboldt's absence as a loss, and advocate for him and his place in science to be venerated much as they were in the nineteenth century. This advocacy lays bare many of the ways in which cultural memory functions, and provides a fascinating look into the constitution of memory sites in a contemporary context. Beyond even this utility, however, the Humboldt memory site provides unprecedented insight into the potential of transcultural memory and transcultural influences on cultural memory. This investigation contends that the confluence of Humboldt representation in the literary works of American and European authors indicates the initiation of a transcultural memory site. The depictions of Humboldt in North America and Europe, and more importantly, the cultural motivations and aspirations behind those depictions, have aligned to such an extent that a transcultural space has been created in which multiple cultures can communicate about pressing needs and concerns while drawing on common points of reference. Rebok's Humboldt and Jefferson and Wulf's The Invention of Nature demonstrate this transcultural coordination most clearly, as both exemplify the ease with which textual representations of Humboldt, and the memory sites they constitute, flow back and forth from European and North American cultural discourses.

Most certainly, the litmus test of any element within cultural memory is its importance and relevance to the current conditions and needs of a given culture. Fittingly, the majority of recent Humboldt texts published in the United States and Europe present Humboldt either as a climate change activist avant-la-lettre, or an embodiment of Enlightenment ideals and their potential. By connecting Humboldt as securely as possible to the pantheon of the Founding Fathers and the Olympus of the early republic, these contemporary authors elevate his relevance in a way that might affect the 
reaction of current audiences on both sides of the Atlantic to the issues often associated with him, be it global warming or enlightened discourse. The texts investigated here demonstrate an effort, whether conscious or subconscious, coordinated or uncoordinated, toward reincorporating Humboldt back into America's active cultural memory. As Andrea Wulf states in the epilogue of The Invention of Nature, "now is the time for us and for the environmental movement to reclaim Alexander von Humboldt as our hero" ([7], p. 337).

Conflicts of Interest: The author declares no conflict of interest.

\section{References}

1. Rebok, Sandra. Humboldt and Jefferson: A Transatlantic Friendship of the Enlightenment. Charlottesville: University of Virginia Press, 2014.

2. Walls, Laura Dassow. The Passage to Cosmos: Alexander von Humboldt and the Shaping of America. Chicago: University of Chicago Press, 2009.

3. Sachs, Aaron. The Humboldt Current: Nineteenth-Century Exploration and the Roots of American Environmentalism. New York: Penguin Books, 2007.

4. Helferich, Gerard. Humboldt's Cosmos: Alexander von Humboldt and the Latin American Journey that Changed the Way We See the World. New York: Gotham Books, 2004.

5. McCullough, David. "Journey to the Top of the World." In Brave Companions: Portraits in History. New York: Simon and Schuster, 1992, pp. 3-19.

6. Appleby, Joyce. Shores of Knowledge: New World Discoveries and the Scientific Imagination. New York: W.W. Norton \& Company, 2013.

7. Wulf, Andrea. The Invention of Nature: Alexander von Humboldt's New World. New York: Alfred A. Knopf, 2015.

8. Assmann, Jan. Das kulturelle Gedächtnis: Schrift, Erinnerung und politische Identität in frühen Hochkulturen. München: C.H. Beck, 2007.

9. Huyssen, Andreas. Present Pasts: Urban Palimpsests and the Politics of Memory. Stanford: Stanford University Press, 2003.

10. François, Etienne, and Hagen Schulze. "Einleitung." In Deutsche Erinnerungsorte. Edited by Etienne François and Hagen Schulze. München: Verlag C.H. Beck, 2001, vol. 3, pp. 9-24.

11. Assmann, Aleida. Der lange Schatten der Vergangenheit: Erinnerungskutlur und Geschichtspolitik. München: C.H. Beck, 2006.

12. Assmann, Aleida. "Canon and Archive." In A Companion to Cultural Memory Studies. Edited by Astrid Erll and Ansgar Nünning. Berlin: De Gruyter, 2010, pp. 97-108.

(C) 2016 by the author; licensee MDPI, Basel, Switzerland. This article is an open access article distributed under the terms and conditions of the Creative Commons Attribution (CC-BY) license (http://creativecommons.org/licenses/by/4.0/). 